\title{
Елена ОГНЕВА
}

\section{ВЕК РЕВОЛЮЦИЙ СКВОЗЬ ПРИЗМУ ИСКУССТВА: К ИСТОРИИ СОЗДАНИЯ РОМАНА АЛЕХО КАРПЕНТЬЕРА «ВЕСНА СВЯЩЕННАЯ» ${ }^{1}$}

Аннотация: В статье речь идет о самом «ангажированном» и самом спорном романе выдающегося кубинского писателя. Алехо Карпентьеру понадобилось восемнадцать лет, чтобы создать произведение, которое находится на пересечении двух литературных координат - «нового латиноамериканского романа» и «романа о кубинской революции». В этой связи в работе рассматривается история и предыстория «романа о кубинской революции», прослеживаются основные этапы его становления. В ходе работы над «Весной Священной» (1978) Карпентьер переосмыслил три варианта замысла («1959», «Серебряные гости» и «Русская из Баракоа»), использовал материалы ранних статей и репортажей, а также воспоминания матери писателя - русской эмигрантки. В статье анализируются художественные особенности этого романа Карпентьера (его жанровая природа, специфическая интертекстуальность, различные уровни прочтения). Писатель, проведя своих персонажей по дорогам XX века, от русской революции до кубинской, выбирает для них особый ракурс восприятия действительности. В центре его внимания - история, постигаемая сквозь призму искусства. Оправдав ожидания одних литературоведов и разочаровав других, «Весна Священная» остается и по сей день открытой для интерпретаций.

Ключевые слова: Алехо Карпентьер, «Весна Священная», новый латиноамериканский роман, роман о кубинской революции, латиноамериканская литература.

(C) 2017 Елена Владимировна Огнева (кандидат филол. наук, ведущий научный сотрудник; Московский государственный университет им. М.В. Ломоносова, Москва) ognelen@hotmail.com

${ }^{1}$ Статья выполнена при поддержке гранта РФФИ № 17-04-00073 «Литературный процесс первой половины XX века в Европе и Америке: направления и школы». 


\title{
Elena OGNEVA
}

\section{THE AGE OF REVOLUTIONS THROUGH THE PRISM OF ART. ON THE HISTORY OF CREATION OF THE NOVEL THE RITE OF SPRING BY ALEJO CARPENTIER}

\begin{abstract}
The article is devoted to the most "politically engaged" and the most controversial novel by the prominent Cuban writer. It took Alejo Carpentier eighteen years to create a work that appeared at the intersection of two literary coordinates: "a new Latin American novel" and "a novel of Cuban revolution". In this regard the author studies both history and prehistory of "a novel of Cuban Revolution", and observes the main stages of its development. In the course of work on The Rite of Spring (1978), three different variants of the novel's plan (1959, Silver Guests, and Russian from Baracoa) were reinterpreted by the writer, the materials of Carpentier's early essays and reportages were used, as well as the memories of his mother, a Russian emigrant. The article analyses the artistic peculiarities of this novel by Carpentier (its genre identity, specific intertextuality, various levels of reading). The fact is that Carpentier, having his characters live through the twentieth century, from the Russian revolution to the $\mathrm{Cu}$ ban revolution, creates a special perspective and perception of reality for them. His focus is laid upon history, comprehended through the prism of art. Justifying the expectations of some literary critics and disappointing others, The Rite of Spring remains open for interpretation up to the present day.
\end{abstract}

Keywords: Alejo Carpentier, The Rite of Spring, the New Latin American novel, a novel of Cuban Revolution, Spanish American Literature.

(C) 2017 Elena Ogneva ( $\mathrm{PhD}$, leading research fellow; Lomonosov Moscow State University, Russia) ognelen@hotmail.com 
Определить границы литературного явления в культуре Латинской Америки всегда непросто, особенно если речь идет о близком сосуществовании или пересечении нескольких традиций. Так произошло и с поздним творчеством кубинца Алехо Карпентьера. Его романы 1970-х гг. ХХ в., входящие в так называемый «второй латиноамериканский цикл», рассматриваются одновременно в нескольких культурных контекстах: как итог его творческого пути, как определенная веха в развитии «нового» латиноамериканского романа, и, естественно, как этап становления кубинской прозы. Именно этот аспект вызывает пристальное внимание исследователей, стремящихся определить место последних романов Карпентьера в кубинской литературе и установить/оспорить связь его творчества с таким явлением, как «роман о кубинской революции».

Это литературное явление, оформившееся уже в первые послереволюционные годы, стало своего рода визитной карточкой кубинской литературы. Возникший как своеобразная сводка с поля боя, роман-репортаж, триумфальное свидетельство победы над одиозным диктатором Батистой, он эволюционировал, втягивая в свое поле черты и признаки разных жанров, менялся от поколения к поколению и, трансформируясь, продолжает существовать и по сей день, когда со дня смерти Алехо Карпентьера в 1980 г. прошло уже несколько десятилетий.

Постепенно «роман о кубинской революции» осваивал все новую и новую проблематику, стремясь охватить буквально все стороны национальной жизни, интерпретируя их с позиций победившей революции. За рубежом он воспринимался как обязательная «художественная иллюстрация» официальной идеологии режима Фиделя Кастро. Кстати, и само выражение «роман о кубинской революции», «роман революции» возникло, как утверждают кубинские литературоведы, из перефразированной цитаты. Достопамятные слова Фиделя Кастро, обращенные к интеллигенции, о том, что, если она идет в ногу с революцией, за ней признаются все права, «вне ее» - никаких ("Dentro de la Revolución - todo, contra la Revolución — ningún derecho"), уже в 1961 г. жестко и однозначно утвердили принцип партийности молодой литературы ${ }^{2}$.

Интересно, что в первые послереволюционные годы такое напоминание вообще могло показаться излишним - ранние образцы «романа о кубинской революции» создавались на волне эйфо-

\footnotetext{
${ }^{2}$ Castro Rus, F. "Palabras a los intelectuales." Revolución. Letras. Arte. La
} Habana: Ed. Letras Cubanas, 1980: 11. 


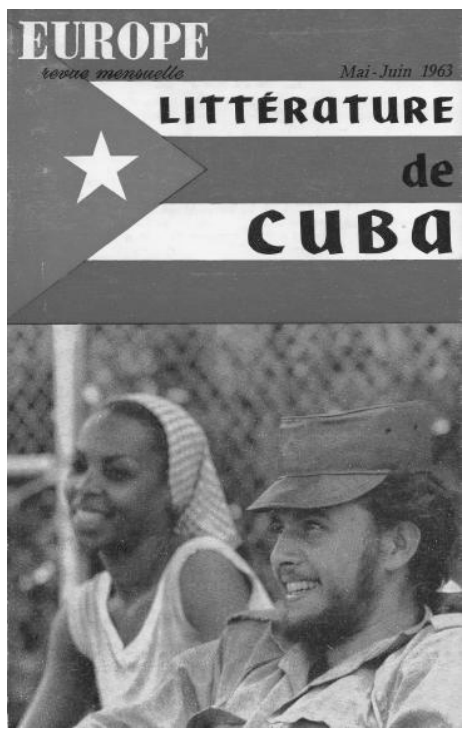

Номер первого журнала Europe (1963), посвященного кубинской литературе

рии и так же восторженно воспринимались, скажем, в Европе. (Яркое тому доказательство, например, тематический спецвыпуск французского журнала Europe 1963 г. ${ }^{3}$, посвященный кубинской литератуpe. С обложки лучезарно улыбается один из молодых «барбудос», а рассказ Эрнесто Че Гевары в журнале соседствует с рассказом будущего диссидента Гильермо Кабреры Инфанте.) До поры, до времени границы феномена не определены.

По мнению многих исследователей, сама история кубинского «романа о революции» трудноотделима от ее предыстории, от такого явления предшествующих революции десятилетий, как «роман о герилье» - о деятельности групп сопротивления диктаторским режимам. Основанный на исторических событиях конца 1920-х — начала 1930-х гг., когда на Кубе существовали две террористические группировки, которые представляли оппозицию режиму диктатора Херардо Мачадо - АВС и Студенческий Директорат - этот роман во многом определил художественные особенности прозы следующего поколения, того, которое вело борьбу не на жизнь, а на смерть против режима ненавистного всем Фульхенсио Батисты. Расцвет романа о городской герилье на Кубе приходится на середину 1950-х гг., на предреволюционное десятилетие.

И происходит любопытный «поворот винта». Написанную живущим в эмиграции Карпентьером в 1955 г. небольшую повесть «Погоня» (El acoso) по инерции воспринимают в русле литературы о терроре, хотя считаться таковой она может лишь по чисто формальному признаку. Герой ее, предавший своих сотоварищей заговорщик, скрываясь от погони, вбегает в концертный зал, где его, в конце концов, настигает пуля мстителей. Эта сюжетная канва прописана Карпентьером без нажима, без особой конкретики. Важнее эстетический эксперимент: пограничная ситуация, смятенное сознание героя изображены на музыкальном фоне.

\footnotetext{
${ }^{3}$ Europe. Littérature de Cuba 409-410 (mai-juin 1963).
} 
Действие длится 46 минут, ровно столько, сколько исполняют Девятую симфонию Бетховена... В этой написанной в сонатной форме повести именно музыка становится просветляющим началом, образом высшей правды в споре о человеке и его ценностях. Прочитана же «Погоня» была иначе, в соответствии с духом времени, в котором уже чувствовалось приближение революционных перемен. Поэтому Алехо Карпентьер автоматически попал в обойму предшественников «романа о кубинской революции».

В 1984 г. кубинский литературовед Дениа Гарсиа Ронда в своей работе о «Погоне» уже будет рассматривать повесть с иной точки зрения, подчеркивая ее общечеловеческий (universal) философский смысл, включит ее проблематику в контекст разговора о трагических оттенках латиноамериканской виоленсии и т.д. ${ }^{4}$ Но эта трактовка станет возможной во многом лишь благодаря тому, что «Весна Священная» (La Consagración de la Primavera, 1978) осветит «обратным светом» скрытые смыслы «Погони»!

Алехо Карпентьер возвратился на свою родную Кубу в мае 1959 г. и сразу включился в работу. Вернулся он, восторженно приветствуя революцию, - в этом, как неоднократно отмечалось, его единомышленниками были и Хулио Кортасар, и Габриэль Гарсиа Маркес. Но, в отличие от них, Карпентьер вернулся ДОМОЙ. Образ возвратившегося скитальца, паломника использовался впоследствии литературоведами для характеристики последних десятилетий творческого пути Карпентьера. Так обыгрывались и темы, и заглавия его произведений 5 .

Уезжал в конце 1920-х гг. начинающий литератор, беглец с чужим паспортом, преследуемый диктатором Мачадо, а вернулся живой классик, один из основоположников «нового» латиноамериканского романа, создавший теорию «чудесной реальности», автор книг, получивших всемирное признание. Кубинская исследовательница Долорес Ньевес Ривера подчеркивает, что ради этого возвращения писатель, достигший в Венесуэле успеха, пренебрег многим, многое бросил 6 , а на родине охотно взялся за несколько дел сразу: возглавил крупнейшее издательство, читал лекции в университете, организовывал музыкальные фестивали, вел цикл радиопередач. Больше двух лет ему понадобилось по-

${ }^{4}$ García Ronda, D. "El Acoso: personajes, signos." Homenaje a Carpentier. La Habana: Universidad de la Habana 223 (sept.-dic. 1984): 91.

${ }^{5}$ См., например, González Echevarría, R. Alejo Carpentier, the Pilgrim at home. Ithaca-London: 1977.

${ }^{6}$ Nieves Rivera, D. "La Consagración de la Primavera en la novela cubana de la Revolución." Homenaje a Carpentier. La Habana: Universidad de la Habana 223 (sept.-dic. 1984): 38. 
этому для завершения масштабного романа «Век Просвещения» (El Siglo de las Luces, 1962).

История молодых кубинцев, чью жизнь навсегда изменили идеи Великой Французской революции и открытый финал романа с крылатыми словами героини: «Надо же что-то делать!» показались кубинскому читателю чем-то вроде пролога к тому, что происходило на Острове Свободы в начале 1960-х гг. И от национального классика стали ждать нового произведения - «романа о кубинской революции».

«Форматируя» это новое для литературы явление, критики, как уже говорилось, в поисках прецедента обращались к прошедшей эпохе. Речь идет не только о «романе о террористах», но даже о романах XIX в., таких, как «Леонела» (Leonela, 1893) Н. Эредиа, «Фраскито» (Frasquito, 1894) Хосе Армаса-и-Сеспедеса и «Эпизоды войны» (Episodios de la Guerra, 1898) Раймундо Кабреры. Традиция, таким образом, выстраивается задним числом: критерием для включения в список становится довольно расплывчатая формула — «обращение к революционным битвам» 7 .

Так что и «Погоня», и «Век Просвещения» обретают в новой национальной действительности специфический контекст, играя роль фундамента, на котором писатель просто обязан возвести здание романа о революции. На протяжении двух десятилетий лейтмотивом большинства интервью Карпентьера становится разговор о ненаписанном/пишущемся «кубинском» романе.

На настойчивые вопросы журналистов он традиционно отвечает, что задумал такой роман - «кубинский» и «революционный». И даже называет заглавие — «Год 1959» $\left(\right.$ El Año 1959) ${ }^{8}-$ говорящее, не вызывающее сомнений. Судя по названию и намекам писателя, это должен был быть роман-хроника недавних событий, соответствующий первому этапу становления кубинского «романа о революции».

В существующих попытках периодизации этой послереволюционной литературы, предложенной как кубинцами Рохелио Родригесом Коронелем и Имельдо Альваресом, так и зарубежными исследователями латиноамериканской прозы Симором Ментоном или Эмилией Юльзари ${ }^{9}$, при всем, порой диаметрально

\footnotetext{
7 Ibid.: 32.

${ }^{8}$ Небольшой отрывок под таким же рабочим названием был опубликован в журнале Casa de las Américas уже в 1964 г., в 1967 г. заговорили о скором завершении работы, однако в 1970 г. мексиканское издательство Siglo XXI заявило, что ранее анонсированное издание романа откладывается на неопределенный срок.

9 Álvarez, I. La novela cubana en el siglo XX. La Habana: Ed. Letras cubanas, 1980; Rodríguez Coronel, R. La novela de la Revolución cubana. La Habana: Ed.
} 
противоположном различии идеологических подходов, существует единодушие в одном пункте: первые романы отражали непосредственное ликование нации, прогнавшей диктатора. Немного погодя, пишет Юльзари, оформится тенденция, которую она свяжет с потребностью в «мифологизации» момента, переживания, воспоминания о 1959 годе.

Литературоведы единодушно подчеркивают, что кубинским романам первых послереволюционных лет свойственны общие недостатки. Раймундо Ласо относит к ним излишнюю публицистичность, отсутствие оттенков в палитре изображения характеров. Черты репортажа вытесняют собственно художественные средства. «Содержание превалирует над формой»- так характеризует кубинские романы этого направления Х. Миранда. «В результате появляется обличительная литература с морализаторским подтекстом. Этическая посылка обуславливает характер анализа, концептуальный заряд подавляет наблюдательность, а риторика - непосредственность» ${ }^{10}$. Резче всех высказался Л. Рохелио Ногерас, заявивший, что подавляющее число романов, опубликованных на Кубе с 1959 по 1966 гг. откровенно слабы в художественном отношении - схематичны, скучны и поверхностны. Х. Миранда, скрупулезно подмечая недостатки этой литературы, тем не менее выделяет в прозе этого периода одно новое качество - отражение изменившегося самосознания нации.

К середине 1960-х гг. кубинская литература осваивает еще один тип героя - человека, покинувшего родину, бегущего от насилия и трудностей. Появляется так называемый роман о времени или рассказ о времени: «Статуи в траве» (Estátuas en la hierba, $1963)$ А. Бенитеса Рохо, «Время прошло» (Pasado el tiempo, 1965) У. Ареналя, «Дом на осадном положении» (La casa sitiada, 1964) С. Леанте, «Тени на белой стене» (En la cal de las paredes, 1971) Г. Эгурена и др. Героям таких романов удается «вырваться» из потока исторического времени, для них оно замирает на том рубеже, где находились стрелки их часов за минуту до победы «барбудос». И дальше они живут уже в своем собственном временно́м измерении, «параллельном» времени молодого государства. Такое существование оборачивается для них застоем, саморазрушением. «Остров вне времени» размывается изнутри, утопия нежизнеспособна. Персонажам остается либо вернуться в «большой мир», как это делает героиня «Статуй в траве», либо

Letras cubanas, 1986; Menton, S. La narrativa de la Revolución cubana. México: Ed. Plaza \& Janés, 1982; Yulzarí, E. La configuración literaria de la Revolución Cubana. De la mitificación a desmitificación. Madrid: Ed. Betania, 2004.

${ }^{10}$ Miranda, F. Nueva literatura cubana. Madrid: Cátedra, 1975: 29. 
умереть в одиночестве («Тени на белой стене»). В противном случае их ожидает безумие («Дом на осадном положении»).

Сначала Карпентьер, видимо, действительно пробует работать в этом ключе, но «моментальный снимок эпохи» не соответствует ни его давно сложившейся художественной манере, ни его философии. Набросок романа о 1959 г., столь часто упоминаемый в интервью, в первозданном виде так и не увидит свет.

По собственному признанию писателя, он «не успевает за революцией», за переменами жизни, темп которых набирает обороты так быстро, что литература должна бы отступить перед возможностями радио и телевидения. Чтобы прочувствовать и сделать предметом романа эти перемены, говорит он, писателю вроде него необходима дистанция, иной временной масштаб.

Если журналисты становятся слишком настойчивыми, Карпентьер приводит в пример советских писателей - Леонова, Всеволода Иванова, Бабеля, чей творческий отклик на революционные события в России был не таким уж спонтанным, им понадобилось время, иногда десятилетия.

Во второй половине 1960-х гг. в «романе о революции» хроника уступает место размышлению, философскому анализу, смене точек зрения. Появляется новый тип персонажа, чье «внутреннее сопротивление» новой кубинской действительности становится причиной его отчуждения и бегства. Делаются попытки осмыслить выбор тех, кто предпочел порвать с Кубой, но, уйдя от чуждой идеологии, отрезал себя от «корней», «истоков». Последнее обстоятельство, вполне созвучное ходу размышлений и художественных построений Карпентьера, заставило его вновь обратиться к ненаписанному «кубинскому роману». Так появляются замысел и черновые варианты романа «Серебряные гости» (Los convidados de plata $)^{11}$.

Однако и этот замысел не будет реализован писателем. С конца 1960-х гг. Алехо Карпентьер на дипломатической работе - в ранге советника-посланника по делам культуры он работает в Париже, где пробудет до самой смерти в 1980 г.

В первые годы в Париже его вклад в развитие «нового» латиноамериканского романа - роман «Превратности метода» $(R e-$ curso del Método, 1974) и повесть «Концерт барокко» (Concierto barroco, 1975). Это произведения, где «кубинская тема» проходит

11 Отрывок под таким названием был впервые опубликован в журнале Bohemia в июле 1965 г. В 1972 г. уже 66-страничный текст под заголовком «Серебряные гости» был опубликован в Монтевидео издательством Sandino как отдельный рассказ. Карпентьер впоследствии утверждал, что в данном случае речь идет о пиратском издании. 
по касательной, остается в подтексте, в повести она возникает в финале.

Во всяком случае, писатель не воспользуется возможностью создать «роман о революции» даже тогда, когда его именитые собратья по перу - Карлос Фуэнтес, Габриэль Гарсиа Маркес и Хулио Кортасар - в 1973 г. запланируют совместную литературную акцию - роман о диктаторе («каждый о своем», о национальном зле). Казалось бы, вот здесь Карпентьеру, не понаслышке знакомому с ужасами диктатуры Мачадо и Батисты, создать полномасштабное «кубинское» полотно, которое ответит наконец ожиданиям соотечественников. Но нет, этого не происходит. Ему оказывается в это время интереснее собирательный образ латиноамериканского плута, кровно связанного с почвой континента, его породившей, пикареска латиноамериканской жизни. Причем некоторые старые замыслы и наброски писателя органично вплелись в художественную ткань «Превратностей метода»: так, был отчасти использован «Портрет диктатора» (El retrato del dictador), политический очерк-памфлет, вышедший в Париже в 1931 г. и мотивы рассказа «Студент» (El estudiante), также написанного в те ранние парижские годы. А черновики, в которых наметились подступы к «кубинскому роману», пока оставались «в столе».

В конце 1970-х гг. в интервью писателя все чаще спрашивают о возможностях использования им богатейшего биографического материала. Ведь и принесшие ему мировую славу «Царство земное» (El Reino de este Mundo, 1949), и «Потерянные следы» (Los pasos perdidos, 1956) основаны на непосредственных впечатлениях о его собственных экспедициях на Гаити и в Венесуэле.

А парижский довоенный опыт? Сюрреалисты, увлеченный спор с которыми он продолжает до последнего часа? А его собственная мать - русская, которую эмигрантская судьба закинула в Швейцарию в самом начале ХХ в., а затем и на далекую Кубу - разве история женщины, сначала в штыки принявшей Октябрьскую революцию, а потом ставшей переводчицей рассказов и повестей советских писателей, не сюжет для романа? А годы его близкой дружбы с легендарной звездой кубинского балета Алисией Алонсо? Карпентьер, охотно касаясь этих тем в разговорах с журналистами, на деле решительно уклонялся от создания своей «беллетризованной биографии». Использовать свой жизненный опыт - это одно, а писать о себе самом - совсем другое, считал он.

Однако многое из рассказов его матери, для которой «Россия», «революция», «эмиграция» были словами, наполненными 

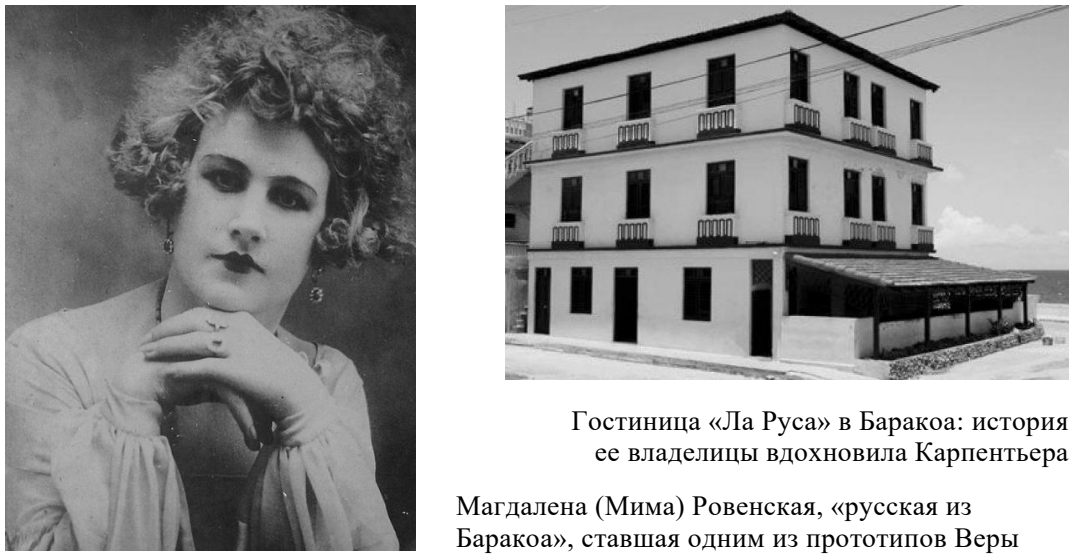

Гостиница «Ла Руса» в Баракоа: история ее владелицы вдохновила Карпентьера

Магдалена (Мима) Ровенская, «русская из

Баракоа», ставшая одним из прототипов Веры

глубоко личным, подчас трагическим смыслом, легло в основу очередного подступа к «большому кубинскому роману». Этот материал, озаглавленный «Русская из Баракоа» (La rusa de Bara$(o a)^{12}$, тоже не станет самостоятельным произведением, но отправится в копилку замыслов, которым суждено будет реализоваться позднее.

Работая во Франции, Карпентьер пристально следит за происходящим на Кубе, часто приезжает, читает все, что пишут кубинские писатели. В 1970-е гг. «кубинский роман о революции» переживает стремительные метаморфозы. «Дело Падильи» в 1971 г. становится причиной размежевания в среде интеллигенции. Писатели, выступившие против цензуры, давления и ограничений со стороны правительства, покидают Кубу, и «кубинский роман о революции» продолжает свое существование за рубежом - уже, по мнению Эмилии Юльзари, как «демифологизирующая» лите-

12 Кроме воспоминаний матери писателя, в главах о Баракоа Карпентьер использовал и другой материал - мотивы биографии загадочной русской красавицы, Магдалены («Мимы») Ровенской-Менесес. Дочь царского офицера, Мима в 13-летнем возрасте покинула революционную Россию, шесть лет провела в эмиграции в разных странах Европы, пока наконец не осела на Кубе. Талантливая танцовщица и певица, Ровенская-Менесес стала женой дипломата, вела светскую жизнь и пользовалась огромным успехом в Гаване 1930-1940-х гг. Ей принадлежал и отель «Мирамар» в Баракоа. В годы диктатуры Батисты она помогала подпольщикам. По преданию, в ее гостинице в Баракоа находили приют и братья Кастро, и Эрнесто Че Гевара. Она пожертвовала городу свои драгоценности. Интересно, что этот отель просуществовал вплоть до совсем недавнего времени, теперь уже под «карпентьеровским» названием — «Русская из Баракоа». 
ратура $^{13}$. Течение как бы раздваивается: оставшиеся на Кубе писатели также не перестают работать, продолжая сложившуюся на родине традицию, но заметно модифицируя ее.

Теперь становится очевидной новая тенденция - уход от сфокусированности на «здесь и сейчас», обращение к давнему или недалекому прошлому, поиск иного масштаба видения современности. В конце 1970-х гг. создаются (а выйдут они уже после смерти Карпентьера) два интереснейших произведения: романы «Пенья Побре» (Peña Pobre, 1980) Синтио Витьера и «Мир, где всего так много» (Un mundo de cosas, 1982) Хосе Солера Пуига. (Во втором из них Карпентьер ощутил бы созвучие своему старому нереализованному замыслу: в романе Солера Пуига рассказывается история, в которой кубинцы без труда узнали жизнь легендарной семьи Бакарди, «отцов» кубинского рома. В 1940-е гг. Карпентьер сам задумывал нечто подобное - роман должен был называться «Рассеянный клан».) Нить воспоминаний, этапы семейной саги соединят в них прошлое и будущее, образ связи времен станет залогом поиска «кубинскости», свободолюбивой основы национального характера, вехами на пути духовных поисков героев. Именно в этом ключе в последние годы своей жизни работает и Карпентьер, завершая свой восемнадцатилетний труд и сводя воедино все разрозненные нити замысла.

Работая над «Весной Священной», Карпентьер последовательно проходил все этапы становления кубинской прозы послереволюционного периода - испробовал разные жанры, художественные перспективы преломления тем, волновавших его соотечественников. Но его постоянное стремление расширить контекст повествования, переводя историю своих героев в план обобщенно-философский и культурологический, не позволяло ему оставаться только в рамках заявленного жанра. В 1978 г. книга, наконец, появилась. Она была воспринята как один из лучших образцов «романа о революции» и «романа о времени». Однако «Весна Священная» естественно вписывается и в контекст «нового» латиноамериканского романа, ибо круг проблем, затронутых Карпентьером, далеко выходит за рамки осмысления национальной действительности.

Многолетний труд писателя увенчался созданием многопланового произведения. «Весна Священная» задумывалась не как исторический роман, но как роман об определенном историческом моменте. А стала философским размышлением о целом веке нашей истории, драматической и бурной, о смысле трагических

${ }^{13}$ Yulzarí, E. La configuración literaria de la Revolución Cubana. De la mitificación a desmitificación. Madrid: Ed. Betania, 2004. 
переломов эпохи, о цене преобразований, об их влиянии на духовный мир человека. Особую тональность эти размышления приобретают благодаря выбору героев: «Весна Священная»это и роман о художнике, продолжающий традицию Гофмана и Бальзака, Ромена Роллана и Томаса Манна. И еще один жанровый аспект «Весны Священной» заставляет вспомнить классическую литературную традицию. Это - роман воспитания, книга об обретении и утрате иллюзий, о цене жизненного опыта и познании «духа времени». Кроме того, это произведение, где постоянно слышится диалог писателя с самим собой, с голосами из его предшествующих романов.

Все жанровые аспекты «Весны Священной» и все уровни прочтения романа - философско-исторический, культурно-мифологический, биографический - связаны с одной ключевой темой, традиционной для поэтики Карпентьера. Это «охота к перемене мест». Но в данном случае, повторяясь и варьируясь на протяжении всего текста, она приобретает все более трагическое звучание. Тема развивается в трех планах: как реальные странствия, на которые обречены герои на протяжении всей жизни; как путь души человеческой, процесс и последствия индивидуального выбора; и как пути истории, до поры до времени неисповедимые.

Всему роману предпослан эпиграф из «Алисы в стране чудес» Льюиса Кэрролла. Карпентьер выбирает отрывок из разговора Алисы с Чеширским Котом:

- Скажите, пожалуйста, куда мне отсюда идти?

- А куда ты хочешь попасть? - ответил Кот.

- Мне все равно... - сказала Алиса.

- Тогда все равно, куда и идти, - заметил Кот.

- Только бы попасть куда-нибудь, - пояснила Алиса.

- Куда-нибудь ты обязательно попадешь, - сказал Кот. Нужно только достаточно долго идти ${ }^{14}$.

В этом отрывке в сжатой форме сформулировано направление движения романа - и сюжетное, и философское, - а также заложена исходная точка, на которой читатель встретится с героями «Весны Священной». Стремление «уйти отсюда» означает для них желание во что бы то ни стало «перечеркнуть», «снять» нестерпимую или недолжную социально-историческую ситуацию.

Повествование ведется от первого лица двумя голосами чередуются внутренние монологи, воспоминания, дневники русской балерины Веры и кубинского архитектора Энрике. Герои выходят навстречу своей судьбе и друг другу из разных точек

${ }^{14}$ Kарпентьер A. Весна Священная. М.: Радуга, 1982. С. 21. 
земного шара. Их пути впервые пересекаются в Мадриде в разгар гражданской войны. С этого и начинается роман, время действия которого - с 1936 по 1960 гг. Однако в их воспоминаниях возникают также другие даты и города. Так, история Веры захватывает Баку 1913 г., революционный Петроград 1917 г., эмигрантские Лондон 1920-х гг. и Париж 1930-х гг. История Энрике Гавану в разгар диктатур Мачадо и Батисты, Париж эпохи сюрреалистической революции и Германию первых лет фашизма.

Роман состоит из восьми частей, каждая из которых включает в себя определенную законченную эпоху в жизни героев, (причем все эти эпохи заканчиваются одинаково - бегством или вынужденным отступлением). Части слагаются из небольших главок, предваряемых эпиграфами. Образы из эпиграфов не раз всплывут в самом тексте глав, цитаты или реминисценции из них пунктиром пронизывают всю ткань романа.

Первое бегство Энрике напоминает известный эпизод биографии самого Карпентьера, который в 1927 г. подписал манифест группы минористов. Потом в Париже писатель отшучивался, небрежно говоря, что на родине попал в тюрьму «только за то, что подписал манифест, где заявил, что кубинские соны предпочитает чарльстону» ${ }^{15}$. На самом деле помимо эстетических приоритетов в манифесте речь шла и о неотложных политических реформах. Подписали его, кроме вчерашних студентов и молодых художников, и профессиональные революционеры... Карпентьер, отбыв срок в Первой тюрьме Прадо, был вынужден спешно и тайно эмигрировать, воспользовавшись документами Робера Десноса. Герой «Весны Священной», как и ее автор, спешно покидает Кубу и отправляется во Францию.

Колыбель просвещения предлагает теперь другую революцию в искусстве. В годы парижского ученичества Энрике предстоит проверить новый тезис: никакие политические движения и кровавые столкновения не завоюют той полной, всеобъемлющей свободы, которую обеспечивает обитателям «провинции снов» la révolution surréaliste. На какое-то время возникает ощущение, что это и есть «истинная современность», смысл эпохи. Это и впрямь так, если сравнивать живой Париж, куда попадает Энрике, с миром его кубинской тетушки.

Эффект подлинности в известной мере достигается специфической интертекстуальностью «Весны священной»: мир кубинских монстров отступает, и читатель погружается в почти документальный «парижский контекст». Энрике стажируется у Ле Кор-

${ }^{15}$ Карпентьер А. Мы искали и нашли себя. М.: Прогресс, 1984. С. 268. 
бюзье, посещает Бретона, цитирует своего друга Десноса, его соседи - Мэн Рей и Висенте Уидобро. А для сравнения можно вспомнить «игрушечный Париж» его кубинской тетки. В день праздника в честь диктатора Мачадо она расставила в саду вокруг своего особняка беседки, имитирующие «Мулен Руж», «Ша Нуар» и «Кабаре дю Неан». Оркестр исполнял парижские мелодии начала века, и гости прогуливались среди декораций, напоминающих о временах Тулуз-Лотрека. То была имитация чего-то, что участники приема сами никогда не видели, и, скорее всего, не видели и исполнители тетиного заказа - как теперь бы сказали, некий «симулякр».

По сравнению с этим симулякром Париж сюрреалистов куда как реален! И самому Карпентьеру в 1929 г. он казался весьма многообещающим, если верить его знаменитому эссе тех лет «Скандал в «Мальдороре» (El escándalo de “Maldoror”). В нем молодой кубинский журналист наставляет собрата-латиноамериканца со старомодным зонтом, открывая провинциалу преимущества Парижа: там [в Латинской Америке. - E.O.] за идеи сажают и убивают, здесь любая безумная идея имеет право на существование. Tам звероподобные вояки дерутся в кабаках по ничтожным пошлым поводам, здесь - поэты крушат столики, вступаясь за честь Лотреамона. Это, с точки зрения Карпентьера, достойно уважения, даже если учесть, что он сам только что порвал с сюрреалистами, поставив свою подпись под памфлетом «Труп II»...

А в представлении героя «Весны Священной» оценка происходящего там и здесь становится явно противоположной. «Здесь говорили, что может пролиться кровь; там лужи крови краснели на тротуарах. Здесь твердили, что пора действовать; там действовали и, зачастую, умирали. Здесь вырабатывали в своем кругу манифест и подписывали; там в тех, чья подпись стояла под манифестом, стреляли, и на лестницах университетов валялись трупы...» ${ }^{16}$. Смысловые акценты смещаются в пользу подлинности латиноамериканского бытия: здесь - фантазируют, а там, на родине - живут. В парижских кафе, мансардах и дансингах действо, Америка же ждет деяния. Но пока Энрике осваивается на этой новой ступени своего ученичества, необходимость в деянии отпадает. Бегство Мачадо открывает новую страницу в кубинской истории.

В Париже герою Карпентьера предстоит испытание любовью и утратой: его подружка, немецкая еврейка, едет проведать родителей в Берлин и исчезает навсегда. Розыски ее в предвоенной

${ }^{16}$ Карпентьер A. Весна Священная. С. 88. 
Германии - новое странствие - подобны сошествию в Ад. Здесь опять, хотя куда более явственно, повторяется та же схема (упование - узнавание - разочарование), что и при встрече с Парижем - «Меккой», «кладезем», «колыбелью».

Окончательно опрокидывается вся система представлений культурного латиноамериканца: здесь никак нельзя объяснить варварство провинциальностью. Оно перестает быть исключительной прерогативой Латинской Америки. Направляясь в мир Гете и Баха, он попадает в кошмарное Зазеркалье, «город мясников» - Веймар. Колыбель разума оказывается колыбелью безумия. Повторяется трагический парадокс, который пытался - и не мог - осмыслить композитор из «Потерянных следов», ожидавший встретить тут «улыбку Эразма», а увидевший «костры инквизиции». Карпентьер ярко, но немногословно описывает ужасы фашизма как таковые, хотя с этой темой связан целый пласт романа. Его формула звучит по-иному: окна домика Гете, что выходят на север, смотрят на Бухенвальд. Точка отсчета не Бухенвальд, а Веймар, то есть норма и идеал, а не их чудовищное извращение, - человек, а не его оппонент, посланец преисподней. Здесь впервые недолжное существование воспринимается не как фарс, но как трагическое действо.

Если в Гаване Энрике был зрителем, теперь он балансирует на линии, отделяющей партер от края сцены. Выморочность, невероятность происходящего, необъяснимая власть маленького бутафора с усиками над умами миллионов людей смущает героя «Весны Священной». Жуткая реальность преломляется в его сознании, где выстраивается вереница оживших литературных образов - из эсперпенто Валье-Инклана, из гимнов Новалиса («ночь и туман»), из «Фауста»... Сначала бросается в глаза театральность страшной действительности: Веймар похож «на прекрасно выполненную театральную декорацию», гостиная в домике-музее «больше подходит для буржуазной драмы», да и самому Гете присваивается звание «великого декоратора».

Нанизывая эти образы один за другим, Карпентьер добивается интереснейшего эффекта - впечатление театральной иллюзии исчезает. «Невсамделишность» ужаса, творящегося в этих мирных бюргерских декорациях, сменяется чувством реальности происходящего. Но раскрашенные задники остаются, невидимые суфлеры подсказывают целой нации что кричать, вскидывая руку ... Энрике входит на эту сцену не из-за кулис, как актер, а из зала, как зритель. Это ощущение героем себя «в декорациях» мира не только связано с одним из важнейших аспектов поэтики романа, оно становится одним из «тезисов», которые предстоит «снять» в ходе философ- 
ских построений Карпентьера. Но пока что Энрике, оказавшись активным участником драмы, должен выбрать себе роль.

Одна из этих ролей - Фауст. Фаустовская тема в творчестве Карпентьера, прежде всего, вызывает в памяти его роман «Потерянные следы». Однако в «немецких» главах «Весны Священной» речь уже не идет об искушении и расплате, но - о Заботе, той, «что во второй части “Фауста" заменяет Мефистофеля» ${ }^{17}$. Вновь и вновь уподобляя себя Фаусту, Энрике занят поисками возлюбленной. Посланец Ада отодвинут на второй план, «ему отведена роль наблюдателя». Силы Ада - система, отнимающая у героя любимую. Ад невидим, но ощущается повсеместно. Сквозь милые и уютные декорации, изображающие немецкий городок XVIII в. «прорастают» то угрожающие, то инфернальные детали. Вот мудрый Лютер толкует Библию на триптихе Лукаса Кранаха в Гердеркирхе - но его фигуру затмевает задний план, изображающий военный лагерь. Вот гипсовая голова Юноны - но Энрике чудится (вспомним опыт Карпентьера-сюрреалиста!) ее окровавленное обезглавленное тело, скрытое в музейном подвале.

Ад меняет свою окраску после бесславного возвращения в Париж без девушки. Теперь это - оставшийся за спиной Аид, куда Энрике-Орфей напрасно спускался за своей Эвридикой. Все быстрее смена в калейдоскопе образов, и вот уже не Орфей, но безутешный рыцарь Desdichado мечется по Парижу, ставшему теперь новой декорацией - пустыней Жерара де Нерваля: “Ma seule étoile est morte”... Но вот рыцарь превращается в простого солдата Интербригады и отбывает в Испанию.

Новое путешествие - бегство от своего прошлого. Но не только. Это бунт «Фауста» и «Орфея» против сил тьмы - за “mehr licht”. Не классовые симпатии, не анализ сути исторических процессов, отнюдь не ангажированность движет героем «Весны Священной». Вдохновляет его ненависть - Карпентьер четко выписывает и акцентирует это слово. И к тем, кто погубил его девушку, и к тем, кто расстрелял Федерико Гарсиа Лорку. Казалось бы, здесь образ врага есть обобщенный образ фашизма... Но нет, срабатывает метод аналогии - и с историческими фигурами, и с образами латиноамериканского бытия. На my сторону баррикад вместе с марокканцами генерала Франко попадают и те, кто расстреливал друзей Энрике в университете Гаваны, и некий испанский маркиз-губернатор, впервые создавший на Кубе в конце XIX в. концентрационные лагеря, и один из отцов немецкого экзистенциализма, вступивший в партию нацистов.

17 Там же. C. 110. 
Отталкиваясь от определений, заключающихся в чужом слове (Орфей, Фауст, Desdichado) Энрике стремится обрести свою подлинную сущность. Какая книга подходит более всего, если читателю угодно спуститься с небес на землю? Конечно же, «Капитал» К. Маркса. Лихорадочно листая «библию» тех, с кем вместе вступает в Интербригаду, Энрике открывает для себя полные жизни образы...

Но возможно ли опоэтизировать текст Маркса?! Карпентьеру это удалось. В результате получается пастиш, где голос автора «Капитала» звучит в унисон с голосом героя «Весны Священной». За словом «товар» встают картины старой Гаваны, с ее бесконечными портовыми складами, пестрота тюков, запахи специй. За словом «стоимость» - колоритнейший Шейлок с его страстным монологом о власти золота. И вот владельцы тюков и шейлоки занимают свои места в сложной системе аналогий, заменяя читателю Маркса классовое чувство. Энрике отправляется воевать не против сил или партий, но «против духа [курсив Карпентьера. - E.O.], живущего в людях, которые “убивают поэтов”» - в самом широком смысле слова. Этим духом заражены и реальные люди; он воплощен и в знакомой веренице образов искусства. Так в восприятии героя искусство и действительность обретают некое подобие равноправия.

Каждый новый виток, новый лик истории оказывается узнаваемым. Возникает эффект déjà lu или déjà vu (в случае если происходящее вызывает ассоциации с живописью). Сегодняшняя реальность воюющей Испании просматривается сквозь знакомые образы мировой культуры, сквозь художественные «свидетельства» самых разных эпох. Они «окликают» друг друга, светят во тьме веков подобно бодлеровским «Маякам».

Таким умением видеть мир Карпентьер одаривает не только героя, но и героиню. Встреча Энрике и Веры происходит в Испании. Русская балерина едет из Парижа навестить раненого жениха-интербригадовца, и видит за окном поезда не столько Пиренеи, сколько «вертикальный пейзаж, вечные декорации» - горы, и не Бискайский залив, а морскую пену у скал Эльсинора, и $l a$ mer, la mer toujours recommencée Поля Валери. Пиренеи отделяют не Францию от Испании, но две части полотна: сзади остаются светлые и безмятежные «Подсолнухи» Ван Гога, а поезд стремительно несется навстречу «Триумфу смерти» Брейгеля, «Капричос» Гойи и «Гернике» Пикассо... Все это сосуществует, все это реальней самой реальности, ибо язык полотен универсален и вечен.

Запечатленное в слове, в красках и звуках, искусство живет своей жизнью, «отделяясь» от воли и планов своих создателей, 
перерастая их замысел. «Марьяна Пинеда» Лорки играется под непредусмотренный аккомпанемент сирен, буханья зениток и взрывов. Звуковой ряд дополняет не декламация, а крик знаменитой Маргариты Ксиргу: она вынуждена перекрикивать звуки реальной войны. Так пьеса пополняется новым звучанием, актуальными смысловыми акцентами. Настоящий страх перед воздушным налетом и катарсис сливаются воедино в душе Веры. Но испанских зрителей трагическая участь Марьяниты волнует куда больше, чем бомбежка, - искусство оказывается сильнее страшной действительности за стенами театра.

Для Веры вне театра театр не кончается, как не кончаются «ужасы войны» за рамками картин в музее Прадо. Вера - участница, причем участница невольная. Путь ее - via dolorosa, испанская земля - земля Голгофы, и плачет она над раненым женихом как «Дева Мария над сыном, снятым с креста» ${ }^{18}$. Так появляется в романе тема мученичества, варьируется, захватывает в свое смысловое поле и библейские образы, и образы Лорки и Пикассо.

Герои Карпентьера (как и сам автор) склонны выстраивать цепочки образов, не ограничиваясь «синхронным срезом» уподоблений, доискиваться скрытых причин и следствий, устанавливать преемственные связи, спрятанные под маской простой аналогии ${ }^{19}$.

Мученичество, жертва - главные образы, с которыми связывается восприятие и истории и собственного жизненного пути героиней «Весны Священной». Поэтому Марьяна Пинеда обретает свое место в цепочке образов, составляющих испанский мартиролог. Вера видит не гордую осанку героини, вышившей знамя мятежникам, но беззащитную шею жертвы, которую удушат гарротой. Марьяна Пинеда сродни Святой Олалии, прелестной замученной девочке, воспетой Пруденцием в «Книге венцов» и Лоркой в «Цыганском романсеро», и самой Вере, у которой «испанская Голгофа» отнимет любимого Жан-Клода. Подобно Олалии Вера четвертована, казнена беспощадной историей.

18 Там же. С. 134.

19 Этот метод сформировался еще в 1940-1950-х гг., что особенно чувствуется в публицистике Карпентьера. В одной из статей он наметил такую цепочку: Монтень, размышляя об открытии Америки, «предсказал» построения Мармонтеля, тот, в свою очередь, — индихенистов рубежа веков, а те ... и т.д. («Жизненность классики», Vitalidad de los clásicos, El Nacional, Caracas, 29.10.1953). Та же схема выстраивается в статье «О страницах одной старой книги» (Sobre las páginas de un viejo libro. El Nacional, Caracas, 10.10.1954), где намечается другая цепочка преемственности: Пруденцийромансеро-Мурильо-Гойя... 
Мир-мартиролог изначально видится ею в категориях мифа: сюжет из нартского эпоса, известный ей с детства, с удивительной яркостью оживает в образах балета Стравинского «Весна Священная». Вера - та самая Дева, что обречена снова и снова платить кровью вечно жаждущим богам, что воплотились для нее в ненавистной идее. История - Молох, отнимающий у нее поочередно все самое дорогое: родину, жениха, возможность танцевать на сцене. Вечная изгнанница, обреченная на все новые Исходы, Вера еще в детстве прочитала знаменитый эпизод из «Алисы в стране чудес» (символично, что опять-таки под гром орудий - петроградских) и навеки осталась девочкой, вопрошающей: куда идти? ${ }^{20}$

Сцены, связанные с Октябрьской революцией, задают в романе еще одну важную тему. Детские впечатления Веры в тот день, когда она читает Льюиса Кэролла и впервые слышит о балете на музыку Стравинского, накрепко связаны с революцией и кровью. Петроградский Октябрь, стук сапог, выстрелы и строки «Интернационала» и «Варшавянки» за дверью будут всю жизнь ассоциироваться со стонами и животными криками от боли, рожающей в ту ночь сестры. Так ассоциативный ряд, сложившийся в 1917 г. в России, обусловит мировосприятие Веры, обреченной скитаться по миру в век революций. Она бежит без направления, без цели, движимая лишь стремлением уйти отсюда, и попадает в ловушки, расставленные ее злейшими врагами - Временем, Историей и Идеей. Все повторяется. Цикличность, повторяемость в мифе о Посвящении Весне (именно так, подчеркивая аспект, связанный с жертвоприношением, звучит по-испански название и балета, и романа) определяет мировидение героини Карпентьера.

Этой устрашающей цикличности она хотела бы противопоставить свое время - неподвижное время искусства и любви, танца и высокого единения душ. Мечта о гармонии посреди вопиющей дисгармонии, плясок смерти и какофонии войны всетаки реализуется. Карпентьер вновь и вновь возвращается к образу кониерта барокко, несущего людям воссоединение и очищение. Испанский концерт в «Весне священной» опять неразрывно связан с идеей синтеза как залога новой гармонии - синтеза не только музыкального, но и расового.

Так, «Интернационал», пропетый на всех языках хором, сплачивает и электризует толпу. Особую же ноту «барочности»

20 Заблудившаяся собеседница Чеширского Кота - другая сторона образа мученицы, девы-избранницы. Когда тема Алисы начинает звучать в романе, возникает неясная, туманная, но перспектива: куда-нибудь ты обязательно попадешь. 
вносит креольский вариант гимна, предложенный мулатом с Гваделупы: “Debou nou toutt kape soufri”... Но кульминацией концерта становятся сольные номера Поля Робсона. Величественная магия его голоса завораживает и заставляет вторить ему «двунадесять языков». Он творит Великое Действо для тех, кто собрался в Испании для Великого Деяния. Наконец-то уравновесились эти стороны бытия, и действа, не неся на себе печати иллюзорности, фальши и неподлинности, обретают свой высший смысл и высшее назначение.

Пока поет Робсон, верится, что Давид победит Голиафа, «черные и белые люди, что слушают эту песню, построят Город Человека, город для человека, свободного от богов..., вечно жаждущих новых жертв...», слушатели переживают экстаз единения, «стираются все и всяческие границы» ${ }^{21}$. И возникает тот самый образ мощной и созидательной силы, которая породит новую гармонию. Несобственно-прямая речь, в которой возникают категории будущего времени, уже не принадлежит ни Вере, ни Энрике. Мы видим все с авторской точки зрения. Голос негра возносит нас вверх, сметая крышу воображаемого собора, - к небу, к планетарному масштабу осмысления бытия, к универсальным ценностям.

Зачарованный Энрике, бок о бок со своими собратьями по оружию, присутствует при осуществлении своего Идеала. Катарсис переживает и Вера, чей Идеал - вневременной полет лебедя Анны Павловой, - казалось бы, никак не совместим с рокочущими звуками спиричуэлов огромного негра: как лед и пламень, как утонченность и сила, как вечная иллюзия и грубость истины.

Их барочный синтез возникает в монологе Отелло, его читает Робсон. В сознании Веры всплывает «невероятное, невозможное, почти абсурдное па-де-де» Робсона и Павловой: черный гигант склонился над умирающим лебедем. Грубая мощь истины оплакивает погубленную иллюзию, без которой не может жить. «Робсон и Павлова по-прежнему летели в ночи, в своем небывалом невиданном танце» ${ }^{22}$.

Это - апофеоз, жизнь в высшем ее проявлении. Бесславное завершение испанской войны, роспуск интербригад и похоронка на Жан-Клода возвещают, что пик в судьбах героев пройден и начинается отрезвление. Испания барочного концерта становится Царством Теней, и Вера повторяет путь и ощущения Энрике, возвращаясь в Париж, - Эвридика без Орфея, Марьяна Пинеда

\footnotetext{
${ }^{21}$ Карпентьер А. Весна Священная. С. 152.

22 Там же. С. 162.
} 
без Педро, покинутая возлюбленная из стихотворения Сан Хуана де ла Крус. Оба героя оставляют уже не Испанию, где прикоснулись к своему идеалу, но «ярко освещенную театральную сцену» ${ }^{23}$, к которой поворачиваются спиной. Впереди новое бегство, очередной Исход. К Парижу подступает новая, теперь понимаемая как «чужая», война.

Соединив свои судьбы, Энрике и Вера, эти обломки кораблекрушения, держат путь на Кубу. Символический для всех карпентьеровских персонажей акт пересечения Атлантики, моста между здесь и там осмысляется как выход героев из хоровода «Плясок смерти» и переход на сцену. «И сцена эта звалась Гаваной» ${ }^{24}$. То есть опять же - из картины в спектакль. Жизнь, на миг показав свое истинное лицо, скрылась за ворохом масок, чередой узнаваемых образов, навеянных европейским искусством. Панорама порта Гаваны напоминает движущуюся декорацию то ли к «Джоконде» Понкьелли, то ли к «Тристану» Вагнера... В Вериной балетной студии оживают картины Дега. И даже мулатка, гордо несущая свое танцующее тело - то ли живой набросок Гогена, то ли обретшая плоть моцартовская Kleine Nachtmusik. А ведь у Карпентьера красивая мулатка - олицетворение самой сущности континента (вспомним кубинскую танцовщицу в «Превратностях метода» или Атали в «Веке Просвещения»)... Свое пока еще определяется через чужое.

Чуть перефразируя высказывания и целые фрагменты из своих статей 1940-1950-х гг., Карпентьер насыщает страницы романа, связанные с ученичеством Энрике, массой автобиографических реалий. Если раньше темы его ранней публицистики вплетались в художественную ткань «Весны Священной» лишь эпизодически (в связи с сюрреалистическим этапом парижской жизни героя, или в связи с его испанскими впечатлениями, когда в романе возникали образы из карпентьеровского цикла «Испания под бомбами» (España bajo las bombas, 1937), то второе открытие Америки герой совершает, шествуя прямо по стопам автора.

Карпентьер, используя свою «теорию контекста», сформулированную в статье «Проблематика современного латиноамериканского романа» ${ }^{25}$, с помощью Энрике приобщает Веру к кубинской жизни. Он открывает своей ученице не только расовые, по-

${ }^{23}$ Там же. С. 199.

24 Там же. С. 201.

25 Идея «контекста, куда насильно включен индивид» принадлежит Сартру, который однажды изложил ее Карпентьеру. Кубинский писатель переосмыслил и расширил концепцию Сартра, сделав свои «контексты» всеохватывающей системой детерминант национального/континентального бытия. 
литические, культурные контексты, но и «контекст хронологического несоответствия», и даже «кулинарный контекст» кубинской жизни. Цель помещения факта в контекст, как писал Карпентьер в той же статье - «Установить - по принципу сходства и различий, - каковы могут быть его отношения со всем миром» ${ }^{26}$. То есть опять-таки возникает и работает система уподоблений и противопоставлений. Но теперь в жизни героя не родное определяется через «тамошнее», - как будто европейское есть некий эталон и универсальный критерий, - а вырабатывается система сравнений двух равноправных величин.

Так начинается собственно «кубинский роман» в романе «Весна Священная». Как мало осталось в нем от набросков «Года 1959»! Именно с кубинской темой теперь связывается история обретения героями гармонии. Познание и самоидентификация лишь часть этой задачи. Другая, не менее важная - реализация своих возможностей. «Быть полезным» - постоянный императив Энрике, продолжение того «Надо же что-то делать!», которое гнало на баррикады Софию из «Века Просвещения». Но жажда деяния теперь постоянно соотносится с величием и чистотой того, испанского идеала, той Идеи, той Солидарности, и сегодняшнее деяние не выдерживает такого сравнения. Отсюда - ностальгическая окрашенность большинства «кубинских глав» «Весны Священной». Энрике часто обращается к своему испанскому прошлому, воскрешает его в своих рассказах, переживает его опять, делясь им с гаванскими студентами. Но жить прошлым уже невозможно, возможно лишь мифологизировать его, пересказывая любимый сюжет.

Попытка пригодиться миру опять заканчивается сомнениями Фауста. Искусство архитектора никому не нужно. Кубинским нуворишам хочется, чтобы Энрике возводил симулякры - вроде «шедевров» в тетушкином саду, дикое отражение их собственных представлений о «хороших домах» Европы. Каждый новый заказ убивает частицу индивидуальности архитектора, ибо владельцы не хотят, чтобы их особняк стал частью того «контекста освещения» и «контекста пропорций», какими одаривает Энрике вновь открытая родина. Чем больше уступаешь, тем язвительнее ухмыляется бес. Архитектору-Фаусту противостоит не философ, не щеголь с петушиным пером. Энрике живописует своего мучителя, пользуясь системой отличий, которую описал Карпентьер в статье о контексте: не дракон под стопой святого Георгия, не зеленый Сатана Орканьи, не чудище Брейгеля, не опереточный

${ }^{26}$ Карпентьер A. Мы искали и нашли себя. С. 43. 
чертик, не странный гость Томаса Манна, - как раньше нанизывались уподобления, теперь громоздятся отрицания. Этот бес константа кубинского бытия, надевший личину Джорджа Вашингтона с долларовой купюры. «Чтобы оказаться в его власти, достаточно принять его дары» ${ }^{27}$. Таков «буржуазный контекст» эпохи.

«Быть полезной» пытается и Вера, открывшая балетную студию. С ее образом связан оригинальный вариант самореализации: она попробует пересказать сюжет собственной жизни, поставив «Весну Священную». Но и образная система, и хореография, и оркестровка балета претерпят существенные изменения, попадая в поле воздействия специфического «расового» контекста. Система аналогий обогатится ярким афрокубинским материалом: оказывается, миф о Деве-Избраннице, принесенной в жертву ради других, знала не только античность и языческая Русь. Карпентьер, поклонник искусства Стравинского и его пропагандист, еще в 1930-е гг. обнаружил в фольклоре кубинских негров сюжет, сходный с тем, что лег в основу либретто «Весны Священной». Теперь этот сюжет открывает Вера, соприкасаясь не только с местной трактовкой мифа, но и с альтернативной, если так можно выразиться, манерой танца. Это единственное место в карпентьеровской «Весне Священной», где оживает «чудесная реальность»: четыре негра, исполнители танца Арара, «в буквальном смысле слова парили в воздухе, не опускаясь на землю» ${ }^{28}$.

Как на земле «чудесной реальности» пересказать сюжет, озвученный Стравинским? (Ведь постановка, перевод на язык жестов тоже есть не что иное как форма пересказа, т.е., опять-таки, поиск подходящей системы аналогий.) Вера ищет эту систему в фольклоре кубинских негров - факт в гаванском обществе 1950-х гг. беспрецедентный. Ее мечты о постижении универсального образного строя, который не делился бы на искусство белых и искусство «кафров» (что оставалось недостижимым идеалом в «Превратностях метода») близки к осуществлению. В ее студии импровизирует под музыку «Весны Священной» танцор-негр из группы «Дьяволов Арара». И совершается чудо: черная фигура парит «как ангел». Небывалый, причудливый синтез традиций, рас, культурной памяти порождает, наконец, искомую «новую гармонию».

Этот очередной барочный концерт становится прообразом новой постановки «Весны Священной», где у героини впервые появится возможность осуществить свой идеал. Будет шанс са-

\footnotetext{
${ }^{27}$ Kарпентьер А. Весна Священная. С. 288.

28 Там же. С. 250.
} 
мой создать что-то подобное фантастическому «полету Робсона и Павловой», что привиделся ей в Испании. Замысел неразрывно связан с идеей синтеза культур. Белые балерины из студии классического танца будут репетировать с танцорами Арара; в оркестре зазвучит кубинский рожок гуиро. Но главное - изменится развязка рериховского либретто: жертвенный ритуал (rito sacramental) сменится весенним обрядом (rito vernal).

Героиня стремится разомкнуть объятия мифа, переписать свою судьбу. Ее спектакль, этот утопический «концерт барокко» раздвинет, кажется ей, декорации пригорода Гаваны, превратив сцену в бескрайнюю площадь. И вновь - повторяется образ предыдущих барочных концертов, созданных Карпентьером - исчезнут старые стены, взлетит крыша, ибо мир преобразит «земная красота, открытая заново...» ${ }^{29}$.

История с ее кровавыми боями ушла теперь со сцены и переместилась в зрительный зал. На сцене осталась Вера, противопоставляющая времени Истории замкнутый отрезок времени своего спектакля, тот, что отстукивает хронометр. Но время зрительного зала неумолимо. И место действия - Гавана конца 1950-х гг. диктует свои правила, о которых Вера старается не знать. Вот она, традиционная тема кубинского «романа о революции»пробуждение, приобщение человека, невозможность оставаться «над схваткой» во времена Батисты.

Но в «Весне Священной» эта традиционная тема разрабатывается нетрадиционно. Сама борьба, подполье, допросы, исчезновение людей, - все это где-то есть, но на заднем плане. Вера видит лишь результаты: свой несостоявшийся спектакль; растерзанные тела танцоров на полу опечатанной студии; Энрике, ночью стирающего чью-то окровавленную одежду, а наутро вынужденного вновь бежать из страны... И таинственная записка: «Возлюбленной Мелибеи в Давосе». Вот когда эстетская игра в аналогии обретает сверхсмысл, став шифром и спасая человеческие жизни! Чернокожий танцор с деревенским именем Каликсто по ассоциации с героями Франсиско де Рохаса назван «возлюбленным Мелибеи». Давос, волшебная гора Томаса Манна, означает Сьерру-Маэстру — лагерь повстанцев...

Вновь ненавистная диктатура становится частью той злой силы, что «убивает поэтов». На насилие героиня привыкла отвечать бегством, и она выбирает очередной Исход. Очередной этап ученичества пройден: остановившееся время искусства не гарантирует спасения. Теперь будет опробован еще один вариант из богатейшего карпентьеровского арсенала - время, идущее вспять.

${ }^{29}$ Там же. С. 323. 
Вера мечтает жить как бы назад [курсив Карпентьера. - E.O.]. Конечно, не повторить буквально сюрреалистическое возвращение к истокам героя одноименного рассказа из сборника «Война времени» (La Guerra del tiempo, 1949) - но «вычесть» себя из общества, из опыта собственной жизни, из невыносимой современности - то есть, в конечном счете, одну утопию сменить другой. Убежище Вера обретает в самой крайней точке кубинского захолустья, nec plus ultra - Баракоа. Отсюда уже некуда идти, это финал пути, предсказанный Чеширским Котом. Дальше только la mer, la mer, toujours recomencée. Так в этой части «Весны Священной» реализуется старый замысел Карпентьера, связанный с темой «острова во времени», которая разрабатывалась кубинской прозой 1960-1970-х гг.

В странствие к истокам кубинского бытия героиня пускается, что немаловажно, вспоминая «дорогу святого Иакова, путь нищих, кающихся, обремененных». Настаивая на ассоциации с другим своим рассказом из «Войны времени»- «Дорога святого Иакова» (El camino de Santiago) - Карпентьер включает Веру в новый контекст, особое интертекстуальное поле, где живут и действуют его персонажи - рыцари нелинейного времени. Баракоа находится в таком отрыве от мира, что напоминает маркесовское Макондо: здесь можно жить, не имея часов. Море величественно, а ливни баснословны. В своем последнем путешествии Вера возвращается по дорогам памяти назад, к первому Исходу, к петроградским пушкам, пока грохот настоящего старинного орудия в форте Баракоа не пробуждает ее к жизни. Известие о революции настигает героиню, живущую «на краю карты, вне календарей». Принимая то, от чего всю жизнь убегала, Вера отказывается от роли жены Лота, от обратного времени как времени неподлинного: прошлым жить нельзя. И миражами жить нельзя, открывается ей в озарении. Так, наконец, «со сцены» героиня сходит «в зал», в реальность, преступая «границу мнимости» ${ }^{30}$.

В последних главах «Весны Священной» ритм все убыстряется. Революционные события, происходящие «за кадром» отражаются в ликующих лицах и криках горожан. Темп все быстрее, словно телеграф отстукивает срочный репортаж, сводку с поля боя. В текст все чаще вторгаются газетные заголовки, радиосводки - Карпентьер пробует освоить стиль первых романов о революции. В результате получается стилизация, где «чужое слово» вновь организует повествование.

Возвращение Энрике, «третье открытие» Кубы связаны с теми частями карпентьеровского замысла, один из ранних вариантов

${ }^{30}$ Там же. С. 429. 
которого проходил под названием «Серебряные гости». Героя ожидает пустой теткин особняк в Гаване, превратившийся в музей ее амбиций - все там замерло на своих местах, когда хозяйка эмигрировала. Неподвижность как пассивное сопротивление переменам выглядит достойнее, чем «вальпургиева ночь» в казино Гаваны, где спускаются целые состояния перед «концом времен». Карпентьер создает жуткий образ Ночи Мертвых, пирующих последний раз: для них играет усталый скрипач с полотен Гольбейна, и шейлоки вопиют, оплакивая утрату золота... Но вот ночь проходит, и призраки покидают «неподвластный им город» ${ }^{31}$.

Перед Энрике стоит противоположная задача - обретение своего «наследства», своего города. Но, как сказано в Книге Исхода, его надо «заслужить» - не у победителей, но у себя самого. Вступая в ряды милисианос и сражаясь на Плайя-Хирон бок о бок с молодыми, Энрике реализует свой утопический вариант бытия. Свершается невозможное: он вновь переживает свой звездный час, свою Испанию, свое мифологизированное прошлое, где когда-то максимально приблизился к идеалу («как в Брунете... но там мы ее проиграли») $)^{32}$. На Плайя-Хирон Фауст, наконец, выкупает свою душу. С Испанией связана и Верина аналогия: там война все отняла у нее, здесь - вернула ей победителя.

Итак, столь давно ожидаемое событие свершилось, роман вышел и был воспринят на Кубе как аргумент в пользу жизнеспособности жанра «романа о кубинской революции», как произведение, не только продолжающее традицию, но и обновляющее ее. «Это ответ на уже ставший риторическим вопрос, существует ли на самом деле роман о кубинской революции» ${ }^{33},-$ пишет Долорес Ньевес Ривера. Называя «Весну Священную» романом «ангажированным» (comprometida) и «партийным» (partidista), кубинская исследовательница связывает его с заключительным этапом творческого пути, который, по ее мнению, завершился изображением «чудесной реальности революции» ${ }^{34}$.

Однако главы, где речь идет о триумфальном шествии революции и описание событий на Плайя-Хирон показались убедительными далеко не всем. Американский литературовед Симор Ментон упрекнул Карпентьера в том, что концовка романа приписана из конъюнктурных соображений. Эта часть «Весны Свя-

31 Там же. С. 454.

32 Там же. C. 465.

${ }^{33}$ Nieves Rivera, D. "La Consagración de la Primavera en la novela cubana de la Revolución." Homenaje a Carpentier. La Habana: Universidad de la Habana 223 (sept.-dic. 1984): 47.

34 Ibid. 
щенной» ему, как и некоторым другим исследователям, показалась искусственной, неубедительной, неожиданной. Нам же представляется, что ничего неожиданного в этих «ангажированных» эпизодах нет. Они проникнуты столь знакомым русскоязычному читателю блоковским мироощущением. И здесь напрашивается параллель с творчеством Хулио Кортасара, воспевшего романтику и «музыку революции» в рассказах «Воссоединение» (La reunión, 1966) и «Тот, кто здесь бродит» (Alguien que anda por ahí, 1977). «Воссоединение» карпентьеровских героев с миром и то, что свидетельствует об их ангажированности, есть не что иное, как очередная попытка обрести гармонию бытия, быть с «другими», связать искусство и действительность, или, как сформулировал это в свое время Кортасар в знаменитом рассказе о Че Геваре, - «творить музыку для людей». И так же, как и у героев Кортасара, происходит это приобщение к истории: не рефлексия, не логическое осмысление, но «прорыв», озарение, чувство в конечном итоге обуславливает выбор, сделанный героями «Весны Священной».

Кажущееся немотивированным, слишком быстрым «пробуждение» героев романа подготавливается скрытым подтекстом литературных реминисценций. Вот, например, столь часто повторяющееся la mer, la mer. Образы последней строфы «Морского кладбища» Поля Валери, любимого стихотворения Карпентьера, переосмысленного им, готовят финал. Вихрь, вырывающий книгу из рук, для героев Карпентьера означает неминуемое возвращение к жизни, «перерастание одежд» книжных образов. Характерно, что из этого же стихотворения заимствован и образ сметенной вихрем крыши, неизменный атрибут «концертов барокко», который у Карпентьера обеспечивает взгляд на событие сверху, из универсума, из будущего.

И по сей день высказывается мнение о том, что пресловутое обновление Карпентьером «романа о революции» происходило под давлением и явилось прямым следствием «выкручивания рук», а в прокрустово ложе жанра материал был уложен благодаря нажиму властей (буквально - "la camisa de fuerza", смирительная рубашка) $)^{35}$. В это верится с трудом, если учесть, что роман дорабатывался и выпускался смертельно больным писателем, знающим, что дни его сочтены, и живущим к тому же в Париже, откуда при желании он мог и не возвращаться.

Наиболее интересным и заслуживающим внимания нам кажется суждение маститого историка латиноамериканской литературы Дональда Шоу. Его, так же, как и многих его зарубежных

${ }^{35}$ Domínguez, Victor Manuel. La novela de la Revolución cubana - URL: https://www.cubanet.org/articulos/la-novela-de-la-revolucion-cubana 
коллег, не убедили кубинские «революционные» главы, в которых он увидел хэппи-энд, достойный «фильмов с участием Джона Уэйна». Более того, он увидел в заключительных главах романа измену писателя самому себе, главному карпентьеровскому философскому принципу, гласящему, что «ни в один из моментов истории человек не волен избегнуть бремени Сизифа» ${ }^{36}$. Однако, думается, это суждение было бы справедливо, будь батальные сцены на Плайя Хирон, окрашенные ностальгией Карпентьера по его молодости времен Гражданской войны в Испании, собственно финальными. Но «магия последней фразы» говорит об ином.

Не стоит считать финал «Весны Священной» мажорным. Плайя-Хирон для героя, как и грядущая постановка «Весны Священной» для героини - их очередной барочный концерт.

В конечном счете самое автобиографическое и самое ангажированное произведение кубинского писателя оказывается «венком» таких концертов - утопических и прекрасных. Идеал пока остается невоплощенным. Но мы совершенствуем жизнь, и жизнь совершенствует нас, и путь совершенствования подобен спирали, и, если в минуту малодушия мы примем отрезок ее за круг, это объяснимо, - утверждает Карпентьер. В нашем масштабе видения они так похожи. Ибо существует огромный разрыв «между кратким отрезком человеческой жизни и долгими годами коллективного свершения. Между тем, что сегодня рассматривается как осуществившаяся, близкая к идеалу реальность, и тем, что предстанет перед нашими глазами и глазами наших потомков, как неполная, незавершенная реальность, над которой еще предстоит трудиться» ${ }^{37}$.

Не случайно финал «Весны Священной» носит открытый характер. Роман заканчивается теми же словами, что и начался балетным счетом («и раз, и-и два, и-и три»...). «Весна Священная» начинается «с земли», «с пола», с терпеливого и безрадостного пока взгляда балерины под ноги, и кончается все той же работой, тяжелым трудом под стук хронометра, который когда-нибудь воплотится в прыжок, в каскад, в полет танцовщицы.

\section{REFERENCES}

Álvarez, I. La novela cubana en el siglo XX. La Habana: Ed. Letras cubanas, 1980.

Castro Rus, F. "Palabras a los intelectuales." Revolución. Letras. Arte. La Habana: Ed. Letras Cubanas, 1980.

${ }^{36}$ Shaw, D.L. Nueva narrativa hispanoamericana. Boom. Postboom. Postmodernismo. Madrid: Ed. Cátedra, 2014: 95.

${ }^{37}$ Карпентьер А. Весна Священная. М.: Радуга. 1982, С. 69. 
Domínguez, Victor Manuel. La novela de la Revolución cubana. Online at https:// www.cubanet.org/articulos/la-novela-de-la-revolucion-cubana

Europe. Littérature de Cuba 409-410 (mai-juin 1963).

García Ronda, D. "El Acoso: personajes, signos." Homenaje a Carpentier. La Habana: Universidad de la Habana 223 (sept.-dic. 1984).

González Echevarría, R. Alejo Carpentier, the Pilgrim at home. Ithaca-London: Cornell University Press, 1977.

Karpent'er, A. My iskali i nashli sebia. Moscow: Progress Publ., 1984.

Karpent'er, A. Vesna Sviashchennaia. Moscow: Raduga Publ., 1982.

Menton, S. La narrativa de la Revolución cubana. México: Ed. Plaza \& Janés, 1982.

Miranda, F. Nueva literatura cubana. Madrid: Cátedra, 1975.

Nieves Rivera, D. "La Consagración de la Primavera en la novela cubana de la Revolución." Homenaje a Carpentier. La Habana: Universidad de la Habana 223 (sept.dic. 1984).

Rodríguez Coronel, R. La novela de la Revolución cubana. La Habana: Ed. Letras cubanas, 1986.

Shaw, D.L. Nueva narrativa hispanoamericana. Boom. Postboom. Postmodernismo. Madrid: Ed. Cátedra, 2014.

Yulzarí, E. La configuración literaria de la Revolución Cubana. De la mitificación a desmitificación. Madrid: Ed. Betania, 2004. 